\title{
Sediment Source Assessment Using Sediment Fingerprints
}

\section{Problem}

Sediment is one of the most common causes of loss of stream-biologic integrity, whether in suspension in the water column, or as deposition on a stream or lake bottom. Fine-grained silts and clays are of particular concern because they can degrade habitat and often carry phosphorus and (or) other contaminants harmful to humans and aquatic life. Sediment-impaired water bodies, usually identified by fair to poor macroinvertebrate index scores, are placed on the 303(d) list of impaired waters, where a sediment Total Maximum Daily Load (TMDL) is developed under the Clean Water Act (https://www.epa.gov/tmdl). In order to effectively manage sediment, it is necessary to identify the sediment sources and locations of "hot spots" of erosion and deposition.

\section{Procedure manual now available for fingerprinting sources of sediment in streams}

The U.S. Geological Survey (USGS) and the U.S. Environmental Agency (EPA) recently published a manual on sediment source identification that includes details on how to conduct a sediment fingerprinting study (Gellis and others, 2016). This Fact Sheet summarizes key points in the sediment fingerprinting approach.

\section{What is Sediment Fingerprinting?}

The sediment fingerprinting procedure establishes a minimal set of physical and (or) chemical properties (tracers) based on samples collected in upland or channel locations identified as potential sources of sediment. These properties are unique for each source within the watershed. Fluvial sediment samples (target sediment) also are collected that exhibit a composite, or "fingerprint" of source properties. Through statistical procedures, the target sediment properties can be matched to their respective upland or channel source "fingerprints" (fig. 1).

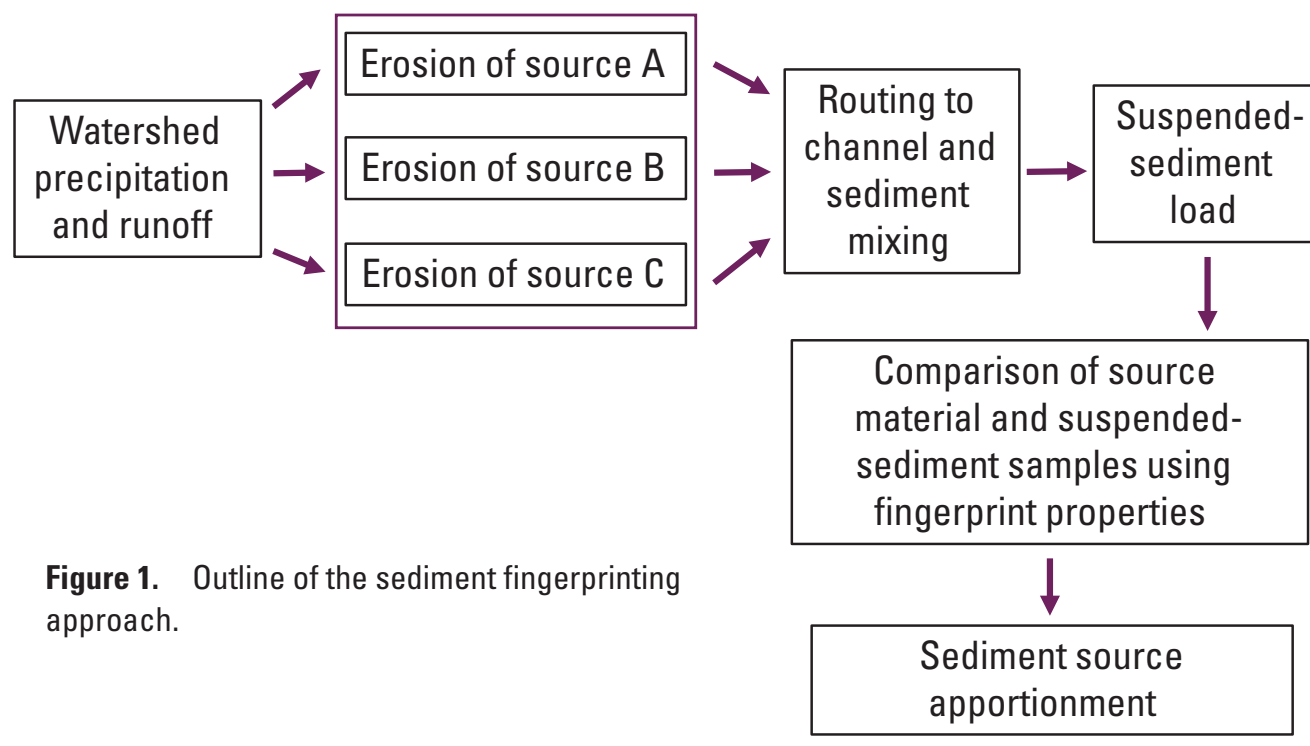

Properties of sediment that have been used as tracers in sediment fingerprinting studies include:

Elemental analysis, mineralogy, stable isotope ratios, magnetic properties, color, and radionuclides.

\section{How Are Potential Sediment Sources Identified?}

Potential sediment sources in the watershed can be identified through Geographic Information System (GIS) analysis, field reconnaissance of the basin, and photogrammetric analyses (such as aerial photographs). Sediment sources include, but are not limited to, upland areas (agricultural land, forest, construction sites, mining areas, urban sources) and the channel (streambanks, channel bed).

Source sampling generally requires 20 to 30 samples per source. In upland areas, samples are collected from the top 1.0 to 2.0 centimeters of the soil surface with a plastic hand shovel. To account for variability in the fingerprint properties at upland sites, sediment is collected across transects and composited into one sample. To obtain a representative sample of streambanks, eroding streambanks are sampled from the bottom to the top of the bank face. Three to five transects spaced 10 meters apart are sampled and composited into one streambank sample.

\section{What Is Target Sediment?}

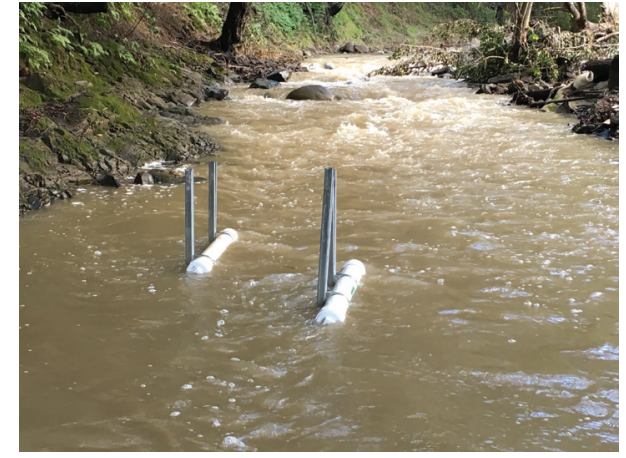

Figure 2. Example of passive samplers used to collect suspended-sediment samples for target sediment. Prior to planning for the target sediment sampling design, it is important to contact the laboratory where the analyses of the various properties selected for the study will be performed to ask questions pertaining to sample mass and holding requirements; for example, whether the samples should be refrigerated. [Photo of Crow Creek, California by Allen Gellis, USGS, January 31, 2017] 


\section{How Can Sediment Fingerprinting Be Used?}

- Targeting sediment sources for watersheds placed on the 303(d) list of impaired waters.

- Assessing the impact of land activities on sediment (construction areas, agricultural, mining, forest fires, timber harvesting, etc.).

- Determining the effect of best management practices (BMPs) on reducing sediment.

- In watersheds where the impact of streambank erosion compared to other sources needs to be determined.

\section{How Are Sediment Sources Determined?}

The USGS has developed a user friendly program (download at https://doi.org/10.5066/f76q1vbx; Sed_SAT) that takes the analyzed source and target sediment, calculates the statistics, and provides sediment-source allocation results with robust error analysis (fig. 3). Results from sediment fingerprinting are shown in figure 4.

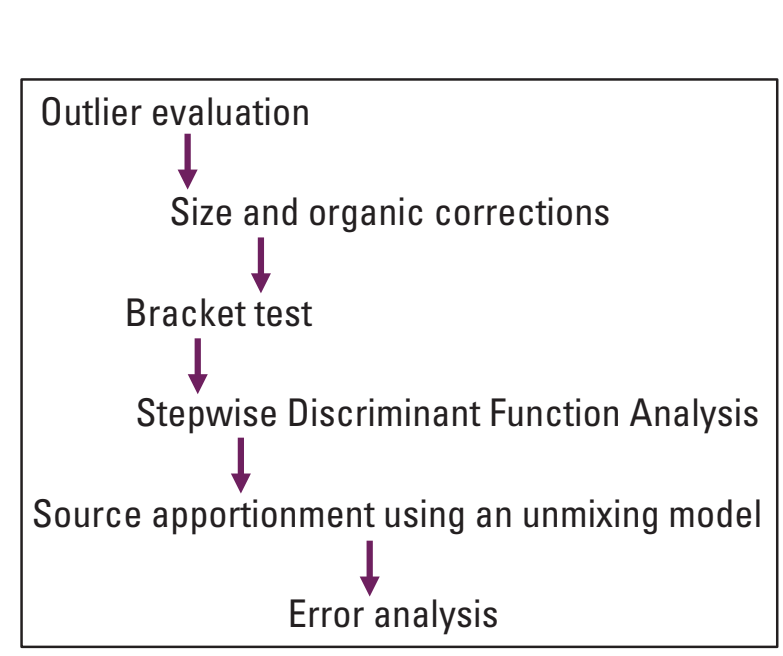

Figure 3. Statistical steps used to apportion sediment in Sed_SAT (Gorman Sanisaca and others, 2017).
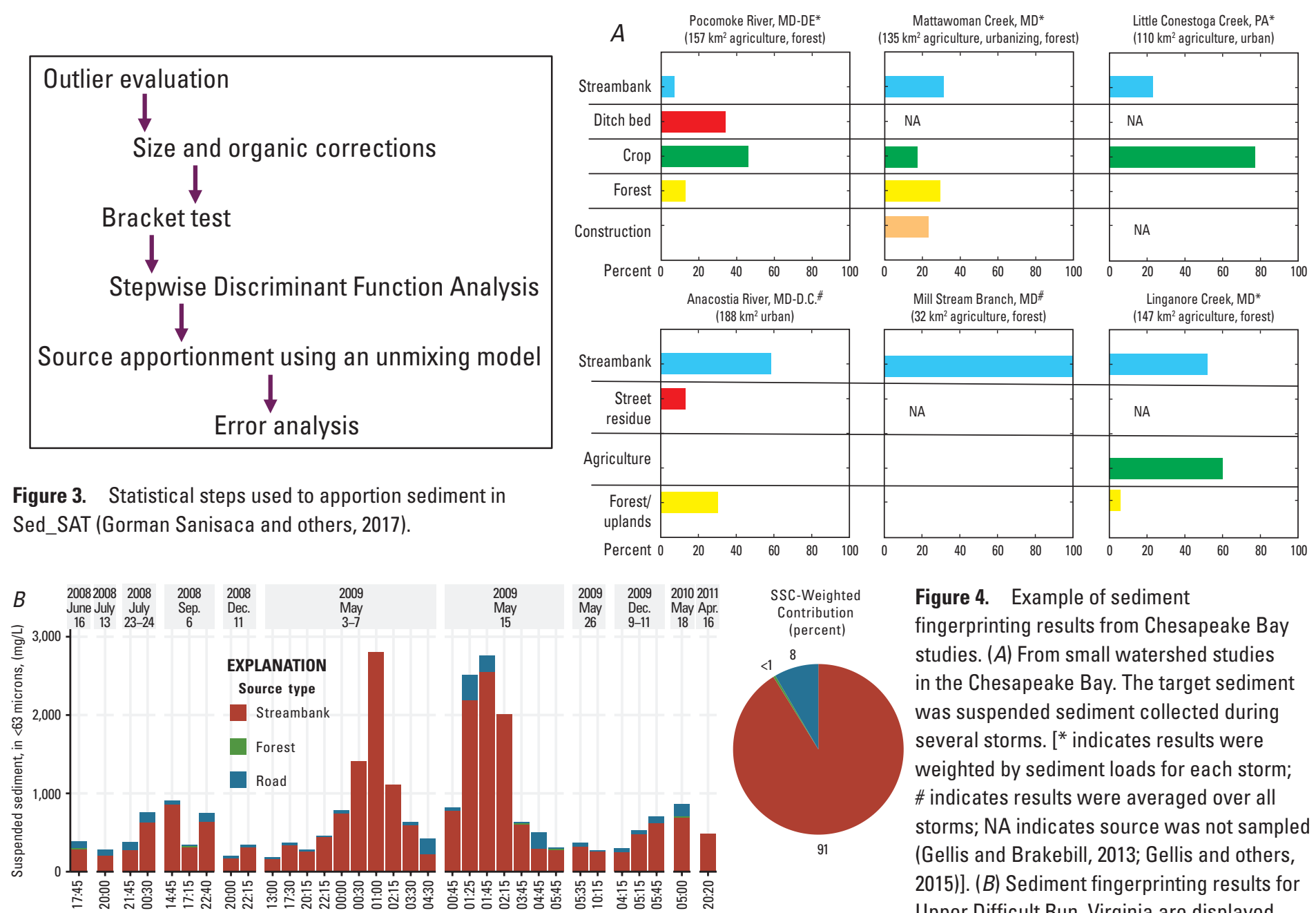

Figure 4. Example of sediment fingerprinting results from Chesapeake Bay studies. (A) From small watershed studies in the Chesapeake Bay. The target sediment was suspended sediment collected during several storms. [ ${ }^{*}$ indicates results were weighted by sediment loads for each storm; \# indicates results were averaged over all storms; NA indicates source was not sampled (Gellis and Brakebill, 2013; Gellis and others, 2015)]. (B) Sediment fingerprinting results for Upper Difficult Run, Virginia are displayed relative to the sediment concentration of each sampled event. [SSC-Weighted Contribution is the sediment-source contribution for all storms weighted by each sample's sediment concentration; <, less than; $\mathrm{mg} / \mathrm{L}$, milligrams per liter; km², square kilometers (Cashman and others, 2018)].

\section{References}

Cashman, M.J., Gellis, A., Gorman Sanisaca, L., Noe, G.B., Cogliandro, V., and Baker, A., 2018, Bank-derived material dominates fluvial sediment in a suburban Chesapeake Bay watershed: River Research and Applications, p. 1-13, DOI: 10.1002/rra.3325, accessed August 28, 2018, at https://onlinelibrary.wiley.com/doi/epdf/10.1002/rra.3325.

Gellis, A.C., and Brakebill, J.W., 2013, Sediment sources and transport in the Chesapeake Bay watershed: U.S. Geological Survey Science Summary, accessed January 23, 2018, at https://chesapeake.usgs.gov/documents/ss-sedimentsourcesandtransport.pdf.

Gellis, A.C., Fitzpatrick, F., and Schubauer-Berigan, J., 2016, A manual to identify sources of fluvial sediment: U.S. Environmental Protection Agency report EPA/600/R-16/210, 106 p., accessed January 24, 2018, at https://clu-in.org/download/contaminantfocus/sediments/Sediment-sources-600R16210.pdf.

Gellis, A.C., Noe, G.B., Clune, J.W., Myers, M.K., Hupp, C.R., Schenk, E.R., and Schwarz, G.E., 2015, Sources of fine-grained sediment in the Linganore Creek watershed, Frederick and Carroll Counties, Maryland, 2008-10: U.S. Geological Survey Scientific Investigations Report 2014-5147, 56 p., accessed October 4, 2017, at http://dx.doi. org/10.3133/sir20145147.

Gorman Sanisaca, L.E., Gellis, A.C., and Lorenz, D.L., 2017, Determining the sources of fine-grained sediment using the Sediment Source Assessment Tool (Sed_SAT): U.S. Geological Survey Open File Report 2017-1062, 104 p., accessed October 4, 2017, at https://doi.org/10.3133/ofr20171062. 